\title{
MONOTONIC TREND AND CHANGE POINTS IN SOUTHERN BRAZIL PRECIPITATION
}

\author{
RITA DE C. F. DAMÉ ${ }^{1}$, CLAUDIA F. A. TEIXEIRA ${ }^{2}$, LUIZ C. S. BACELAR ${ }^{3}$, \\ ANTONIONY S. WINKLER ${ }^{4}$, JACIRA P. DOS SANTOS ${ }^{5}$
}

\begin{abstract}
Scientific evidence on climate changes at global level has gained increasing interest in the scientific community in general. The impacts of climate change as well as anthropogenic actions may cause errors in hydro-agricultural projects existent in the watershed under study. This study aimed to identify the presence or absence of trend in total annual precipitation series of the watershed of the Mirim Lagoon, state of Rio Grande do Sul-RS / Brazil / Uruguay (Brazilian side) as well as to detect the period in which they occurred. For that, it was analyzed the precipitation data belonging to 14 weather stations. To detect the existence of monotonic trend and change points, it was used the nonparametric tests of Mann-Kendall and Mann-Whitney, the " $t$ " test of Student for two samples of unpaired data (parametric), as well as the technique of progressive mean. The Weather Station 3152014 (Pelotas) presented changes in the trend in the series of annual precipitation in the period from 1953 to 2007. The methodologies that use subdivided series were more efficient in detecting change in trend when compared with the Mann-Kendall test, which uses the complete series (from 1921 to 2007).
\end{abstract}

KEYWORDS: parametric and nonparametric test, climate change, trends change.

\section{TENDÊNCIA MONOTÔNICA E PONTOS DE MUDANÇA NA PRECIPITAÇÃO NO SUL DO BRASIL}

RESUMO: Evidências científicas sobre mudanças climáticas em nível mundial vêm despertando interesses crescentes na comunidade científica. Os impactos causados pelas alterações climáticas e ações antropogênicas podem ocasionar erros nos projetos hidroagrícolas na bacia hidrográfica em estudo. O presente trabalho foi conduzido com o objetivo de identificar a presença ou a ausência de tendência nas séries de precipitação total anual da bacia hidrográfica da lagoa Mirim-RS/Brasil/Uruguai (lado brasileiro), bem como detectar o período em que estas ocorreram. Para tanto, foram analisados os dados de precipitação pertencentes a 14 estações climatológicas. Para detectar a existência de tendência monotônica e de pontos de mudança, foram utilizados os testes não paramétricos de Mann-Kendall e Mann-Whitney, o teste " $t$ " de Student para duas amostras de dados não pareados (paramétricos), bem como a técnica da média progressiva. A estação 3152014 (Pelotas) apresentou alteração na tendência, na série de precipitação, no período de 1953 a 2007 . As metodologias que utilizam séries subdivididas foram mais eficientes na detecção de alteração de tendência, comparativamente ao teste de Mann-Kendall, que utiliza a série completa (1921 a 2007).

PALAVRAS-CHAVE: teste paramétrico e não paramétrico, mudança climática, alteração de tendência.

\footnotetext{
${ }^{1}$ Professora Associada,- Centro de Engenharia, UFPel, Pelotas - RS, ritah2o@hotmail.com

${ }^{2}$ Professora Adjunta, Centro de Engenharia, UFPel, Pelotas - RS.

${ }^{3}$ Meteorologista, CEMADEN, SP.

${ }^{4}$ Doutorando do Curso de Pós-Graduação em Manejo da Água e Conservação do Solo, FAEM/UFPel, Pelotas - RS,

${ }^{5}$ Mestranda do Curso de Pós-Graduação em Manejo da Água e Conservação do Solo, FAEM/UFPel, Pelotas - RS.

Recebido pelo Conselho Editorial em: 21-9-2011

Aprovado pelo Conselho Editorial em: 8-10-2012
} 


\section{INTRODUCTION}

Since the 1980s, scientific evidence on climate changes at the global level has attracted increasing interests in the public and the scientific community in general. In 1988, the World Meteorological Organization (WMO) and the United Nations Environment Programme (UNEP) established the "Intergovernmental Panel on Climate Change" (IPCC, 2007), aiming to support, with scientific studies, the assessments of climate and the climate changes scenarios for the future. According to TRENBERTH et al. (2007), the fourth scientific report of the IPCC AR4 presents scientific evidence of climate change that can significantly affect the planet, especially in extreme weather, with higher accuracy in less developed countries in the tropical region.

It happens, however, that when using the hydrological data of precipitation and flow of hydraulic structures in designs, for example, it is assumed that the time series are stationary, i.e., they do not exhibit changes in their statistical characteristics along time (TUCCI, 2005). Knowledge about possible climatic-hydrologic scenarios and the uncertainties involved may help estimating water demands and also defining environmental policies of use and management of water for the future (MARENGO, 2007). Thus, the impacts caused by climate changes and anthropogenic actions in the watershed under study may cause errors in the projects of the hydraulic system of the site (TEIXEIRA et al., 2011).

SILVA \& AZEVEDO (2008) investigated the occurrence or absence of climate change from 1970 to 2006, in some microregions of the state of Bahia-BA, Brazil, using indices of trends calculated from the data of daily precipitation and daily temperature. The results show that there are positive trends of climate changes, attributed to large-scale circulation, while the intensity of precipitation may influence climate variability.

The study of BLAIN (2010) aimed to detect climate trends and variations in eight series of total annual precipitation of the state of São Paulo-SP, Brazil, using parametric and nonparametric test. It was concluded that in $50 \%$ of localities there was change in the trend of precipitation patterns.

SILVA et al. (2011) analyzed the daily precipitation data from 600 weather stations of precipitation in northeastern Brazil. To evaluate the trends of the time series, they used the MannKendall test and, after detection, these were removed for preparation of correlograms. The authors concluded from the correlograms of precipitation that significant trends occurred to the confidence limit of $95 \%$ in some of the 600 stations analyzed.

LANG \& RENARD (2007) analyzed flow data from 200 hydrometric series of France, with 48 years of records, and found out that no consistent and widespread climate trend may explain the evolution of the hydrological regime in the hydrological extremes. The authors stated that, due to non-linearity exhibited by precipitation, there is great difficulty in determining the relation between the increase or decrease of rain blade. In this sense, an assessment of the analysis of trends of precipitation series is necessary, since this variable is the main water inlet in the watershed.

In the southern half of the state of Rio Grande do Sul, it is the Mirim Lagoon watershed, considered as transboundary, set in part in Brazil $\left(29,250 \mathrm{~km}^{2}-47 \%\right)$ and in Uruguay $\left(33,000 \mathrm{~km}^{2}\right.$ 53\%). On the Brazilian side, it is composed of the subwatersheds: São Gonçalo, Arroio Grande, Arroio Chasqueiro and Coastal, while the Uruguayan side has the Tacuari, Cebollati, Sarandi and the São Miguel watershed. In Mirim Lagoon watershed, there are 54 precipitation stations, whose information has not yet been fully exploited, for evidence of changes in precipitation patterns. Thus, the aim of this study was to identify the presence or absence of trend in the series of total annual precipitation in Mirim Lagoon watershed RS-Brazil / Uruguay (Brazilian side), as well as to detect the period in which they occurred. 


\section{MATERIAL AND METHODS}

This study was carried out from the data of annual precipitation of Mirim Lagoon watershed RS-Brazil / Uruguay, located between parallels $31^{\circ} 30^{\prime}$ and $34^{\circ} 30^{\prime} \mathrm{S}$ and between the meridians $52^{\circ}$ and $56^{\circ} \mathrm{W}$. It was analyzed the data of precipitation at 54 weather stations belonging of the watershed - Brazilian side, obtained from the database of the National Water Agency (ANA, 2011). From 54 stations, only the data of 14 were actually analyzed, to detect long-term trend and the period in which they occurred, since the 40 remaining stations presented data period less than 10 years of age (XU et al., 2003 ), which is a restriction imposed by the statistical methods used. Table 1 lists the characteristics of precipitation stations used for performing the study.

TABLE 1. Characterization of weather stations of Mirim Lagoon watershed RS-Brazil - Brazilian side.

\begin{tabular}{lccccc}
\hline Station & Name & $\begin{array}{c}\text { Latitude } \\
(\mathrm{S})\end{array}$ & $\begin{array}{c}\text { Longitude } \\
(\mathrm{W})\end{array}$ & $\begin{array}{c}\text { Altitude } \\
(\mathrm{m})\end{array}$ & $\begin{array}{c}\mathrm{N} \\
\text { (years) }\end{array}$ \\
\hline 3152003 & Canguçu & $31^{\circ} 24^{\prime} 16^{\prime}$, & $52^{\circ} 40^{\prime} 24^{\prime}$, & 400 & 25 \\
3152005 & Vila Freire & $31^{\circ} 40^{\prime} 10^{\prime}$, & $52^{\circ} 46^{\prime} 22^{\prime}$, & 250 & 22 \\
3152008 & Granja São Pedro & $31^{\circ} 40^{\prime} 22^{\prime}$, & $52^{\circ} 10^{\prime} 40^{\prime}$, & 3 & 29 \\
3152014 & Pelotas & $31^{\circ} 45^{\prime} 00^{\prime}$, & $52^{\circ} 21^{\prime} 00^{\prime}$, & 13 & 87 \\
3152016 & Ponte Cordeiro Farias & $31^{\circ} 34^{\prime} 26^{\prime}$, & $52^{\circ} 27^{\prime} 47^{\prime}$, & 40 & 31 \\
3153004 & Ferraria & $31^{\circ} 44^{\prime} 15^{\prime}$, & $53^{\circ} 03^{\prime}, 14^{\prime}$, & 200 & 29 \\
3153007 & Pedras Altas & $31^{\circ} 44^{\prime} 00^{\prime}$, & $53^{\circ} 35^{\prime} 00^{\prime}$, & 380 & 23 \\
3153008 & Pinheiro Machado & $31^{\circ} 34^{\prime} 39^{\prime}$, & $53^{\circ} 22^{\prime} 37^{\prime}$, & 440 & 40 \\
3153009 & Piratini & $31^{\circ} 26^{\prime} 00^{\prime}$, & $53^{\circ} 06^{\prime} 00^{\prime}$, & 345 & 22 \\
3252005 & Pedro Osório & $32^{\circ} 00^{\prime} 22^{\prime}$, & $52^{\circ} 39^{\prime} 10^{\prime}$, & 20 & 28 \\
3253001 & Arroio Grande & $32^{\circ} 14^{\prime} 14^{\prime}$, & $53^{\circ} 05^{\prime} 23^{\prime}$, & 3 & 39 \\
3253003 & Granja Osório & $32^{\circ} 57^{\prime} 14^{\prime}$, & $53^{\circ} 07^{\prime} 08^{\prime}$, & 3 & 39 \\
3253004 & Herval & $32^{\circ} 01^{\prime} 43^{\prime}$, & $53^{\circ} 23^{\prime} 52^{\prime}$, & 260 & 36 \\
3253005 & Jaguarão & $32^{\circ} 33^{\prime} 00^{\prime}$, & $53^{\circ} 23^{\prime} 00^{\prime}$, & 47 & 24 \\
\hline
\end{tabular}

Initially, it was performed for the studied series an exploratory graphical analysis of time series prior to statistical tests, whose analysis is part of a set of techniques known as "EDA Exploratory Data Analysis" (KUNDZEWICZ \& ROBSON, 2004; ALEXANDRE et al., 2010).

Still in exploratory character, it was used the progressive mean (FRANCO \& GODÓI, 1946), consisting of:

$$
y_{i}=\frac{x_{i}+4 x_{i+1}+6 x_{i+2}+4 x_{i+3}+x_{i+4}}{16}
$$

In which,

$\mathrm{y}_{\mathrm{i}}$ - point for the line alignment corresponding to the mean data $\mathrm{x}_{\mathrm{i}+2}$, and

$\mathrm{x}_{\mathrm{i}}, \mathrm{x}_{\mathrm{i}+1}, \mathrm{x}_{\mathrm{i}+2}, \mathrm{x}_{\mathrm{i}+3}, \mathrm{x}_{\mathrm{i}+4}$ - five consecutive values.

The progressive mean was used to investigate if the annual precipitations have been changing continuously. If there is a decreasing trend, the line representing the progressive mean begins above that arithmetic mean, cuts it at some point and always remains below it. When, instead, the trend is to increase the precipitation, the configuration of the progressive mean develops in the reverse position.

After visual identification of the behavior of trend, parametric and nonparametric tests were applied to accept or reject the null hypothesis, $\mathrm{H}_{0}$, which refers to the lack of change in trend in the population from which the data sample was removed, while the alternative hypothesis, $\mathrm{H}_{1}$, refers to the existence of the trend records. 
To test the hypothesis of long-term trend and the change points, the methodologies used were based on: (a) checking the existence or not of monotonic trend, and (b) detecting change points, in case they occur. For that, nonparametric tests of Mann-Kendall (existence of monotonic trend) and Mann-Whitney (change points) were used, as well as the "t" test of Student for two samples of unpaired data (parametric).

The identification of the period in which the series should be subdivided was based on visual observation of the behavior of the moving average with lag $(k)$ equal to 10 , compared with the mean of the total annual values precipitated (XU et al., 2003).

Parametric and nonparametric tests were chosen because the first ones present, in general, higher robustness, and they may be applied even when there are small deviations of normality or of variance between the samples. Moreover, the nonparametric data should be used when the data do not fit the normal distribution.

To verify the existence or not of monotonic trend, it was used the nonparametric test of MannKendall (XU et al., 2003), and the test statistic given by expression (2):

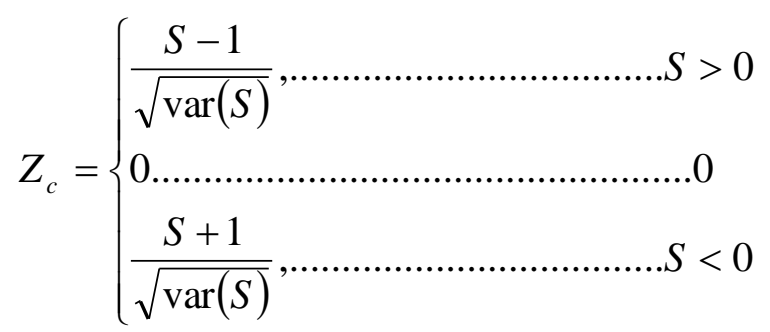

In which,

Zc - test statistic;

$\mathrm{S}$ - test statistic which follows the normal distribution, whose mean $\mathrm{E}($.$) and variance var (.),$ mathematically represented by the expressions (3), (4) and (5), respectively.

$$
\begin{aligned}
& E(S)=0 \\
& S=\sum_{i=1}^{n-1} \sum_{k=i+1}^{n} \operatorname{sgn}\left(x_{k}-x_{i}\right) \\
& \operatorname{var}(S)=\frac{n(n-1)(2 n+5)}{18}
\end{aligned}
$$

In which,

$\mathrm{x}_{\mathrm{k}}$ and $\mathrm{x}_{\mathrm{i}}$ - values contained in the sample with order $\mathrm{k}$ and $\mathrm{i}$, respectively;

$\operatorname{sgn}(\theta)$ - equals to 1,0 , and -1 if $\theta\left(x_{k}\right.$ and $\left.x_{i}\right)$ is greater, equal or less than zero respectively;

$\mathrm{n}$ - sample size.

When there are repeated values in the data sample, the calculation of the variance $(\operatorname{var}(\mathrm{S}))$ is given by the expression (6):

$$
\operatorname{var}(S)=\frac{n(n-1)(2 n+5)-\sum_{i=1}^{n} t_{i}(i)(i-1)(2 i+5)}{18}
$$

The null hypothesis is accepted if $\left|Z_{c}\right| \leq Z_{1-\alpha / 2}$, in which $Z_{1-\alpha / 2}$ is the quartile of the standard normal distribution corresponding to the level $\alpha(0.05)$ of probability, used to the test application.

To detect the occurrence or not of the change points in the precipitation series analyzed, it was used the Mann-Whitney test (CHEN et al., 2007). To apply the test, it is necessary to section the 
data series $X=\left(x_{1}, x_{2}, x_{3}, \ldots, x_{n-1}, x_{n}\right)$, such that $Y=\left(x_{1}, x_{2}, x_{3}, \ldots, x_{n 1}\right)$ and $Z=\left(x_{n+1}, x_{n+2}, x_{n+3}, \ldots\right.$ ,$\left.X_{n 1+n 2}\right)$. The statistics of the Mann-Whitney test is given by expression (7):

$$
Z_{c}=\frac{\sum_{t=1}^{n_{1}} r\left(x_{t}\right)-n_{1}\left(n_{1}+n_{2}+1\right) / 2}{\left[n_{1} n_{2}\left(n_{1}+n_{2}+1\right) / 12\right]^{1 / 2}}
$$

In which,

$\mathrm{r}\left(\mathrm{x}_{\mathrm{t}}\right)$ - order of observations, and

$\mathrm{n}_{1}$ and $\mathrm{n}_{2}$ - number of elements of sub-samples $\mathrm{X}$ and $\mathrm{Y}$, respectively.

Besides the Mann-Whitney test, it was also applied the Student " $t$ " test (MELLO \& SILVA, 2009) for two unpaired samples. For this, there was homogeneity of variances (BLAIN, 2010), and the samples were considered homoscedastic. To implement the " $t$ " test, it was accepted the same section of the data series used in the Mann-Whitney test (CHEN et al., 2007).

From expressions (8) and (9), it was obtained the statistics of the " $t$ " test for unpaired data.

$$
\begin{aligned}
& t=\frac{X_{A}-X_{B}}{\sqrt{s^{2}\left(\frac{1}{n_{A}}+\frac{1}{n_{B}}\right)}} \\
& s^{2}=\frac{\left(n_{A}-1\right) s_{A}^{2}+\left(n_{B}-1\right) s_{B}^{2}}{n_{A}+n_{B}-2}
\end{aligned}
$$

In which,

$\mathrm{s}^{2}$ - variance;

$\mathrm{X}_{\mathrm{A}}$ and $\mathrm{X}_{\mathrm{B}}$ - sample means of precipitation values of the sectioned series, and

$\mathrm{n}_{\mathrm{A}}$ and $\mathrm{n}_{\mathrm{B}}$ - length of the subdivided series, respectively.

\section{RESULTS AND DISCUSSION}

Table 2 shows some descriptive statistics of the precipitation values from 14 stations analyzed. The coefficient of variation (C.V.) values obtained were from 0.17 to 0.27 , and they were lower than the ones found in the BLAIN et al. (2009) study, which analyzed the sample variability of the parameters of the gamma distribution, relative to monthly series of precipitation in regions of Campinas-SP and Pelotas-RS. To this location, the authors found CV equal to 0.41, higher than that found at station 3152014 (Pelotas), whose value was 0.23 . The disparity between the values of coefficients of variation is due to the fact that these authors analyzed monthly series of precipitation, which typically exhibit higher variability than annual series. For all stations, the coefficient of asymmetry $(\mathrm{Ca})$ ranged from 0.38 to 0.75 , characterizing the non-occurrence of the normality of frequency distribution in the data $(\mathrm{Ca}=0)(\mathrm{QUADROS}$ et al., 2011).

Figure 1 shows the series of annual precipitation, its mean and the moving average with lag $(q)$ equals to 10 for 14 stations analyzed. From visual observation of the behavior of the moving average compared to the mean of the total annual precipitation was possible to identify the period in which the series should be subdivided, according to the trend change in relation to arithmetic mean. Considering, for example, the station 3152003, whose values of the series comprise the years 1966 to 1990 , it was observed that until the year 1983 the precipitation values composing the moving average are below the mean sample value, indicating the subdivision point in two sub-periods (from 1966 to $1983, \mathrm{n}=18$; from 1984 to $1990, \mathrm{n}=7$ ). 
TABLE 2. Descriptive statistics of precipitation values from the 14 weather stations analyzed.

\begin{tabular}{rcccccrr}
\hline Station & Mean $(\mathrm{mm})$ & $\begin{array}{c}\text { Stand. Dev. } \\
(\mathrm{mm})\end{array}$ & $\mathrm{CV}$ & $\mathrm{Ca}$ & $\begin{array}{c}\text { Max. } \\
(\mathrm{mm})\end{array}$ & $\begin{array}{c}\text { Min. } \\
(\mathrm{mm})\end{array}$ & $\begin{array}{c}\text { Amplitude } \\
(\mathrm{mm})\end{array}$ \\
\hline 3152003 & 1617.5 & 372.3 & 0.23 & 0.46 & 2346.0 & 1051.2 & 1294.8 \\
3152005 & 1563.8 & 327.3 & 0.21 & 0.49 & 2128.0 & 938.6 & 1189.4 \\
3152008 & 1278.3 & 256.6 & 0.20 & 0.43 & 1828.4 & 825.4 & 1003.0 \\
3152014 & 1312.5 & 305.4 & 0.23 & 0.51 & 2186.3 & 662.1 & 1524.1 \\
3152016 & 1418.8 & 247.5 & 0.17 & 0.42 & 1843.4 & 890.5 & 952.9 \\
3153004 & 1543.0 & 395.1 & 0.26 & 0.67 & 2542.4 & 907.2 & 1635.2 \\
3153007 & 1369.8 & 283.5 & 0.21 & 0.48 & 1858.0 & 801.9 & 1056.1 \\
3153008 & 1530.5 & 357.9 & 0.23 & 0.75 & 2708.0 & 841.9 & 1866.1 \\
3153009 & 1371.2 & 255.9 & 0.19 & 0.49 & 984.1 & 1982.6 & 998.5 \\
3252005 & 1307.5 & 222.0 & 0.17 & 0.44 & 873.5 & 1747.0 & 873.5 \\
5253001 & 1295.5 & 323.6 & 0.25 & 0.38 & 554.2 & 2064.6 & 1510.4 \\
3253003 & 1224.9 & 258.6 & 0.21 & 0.38 & 712.6 & 1931.9 & 1219.3 \\
3253004 & 1483.3 & 337.5 & 0.23 & 0.39 & 733.8 & 2593.0 & 1859.2 \\
3253005 & 1344.5 & 361.4 & 0.27 & 0.48 & 748.4 & 2239.7 & 1491.3 \\
\hline
\end{tabular}
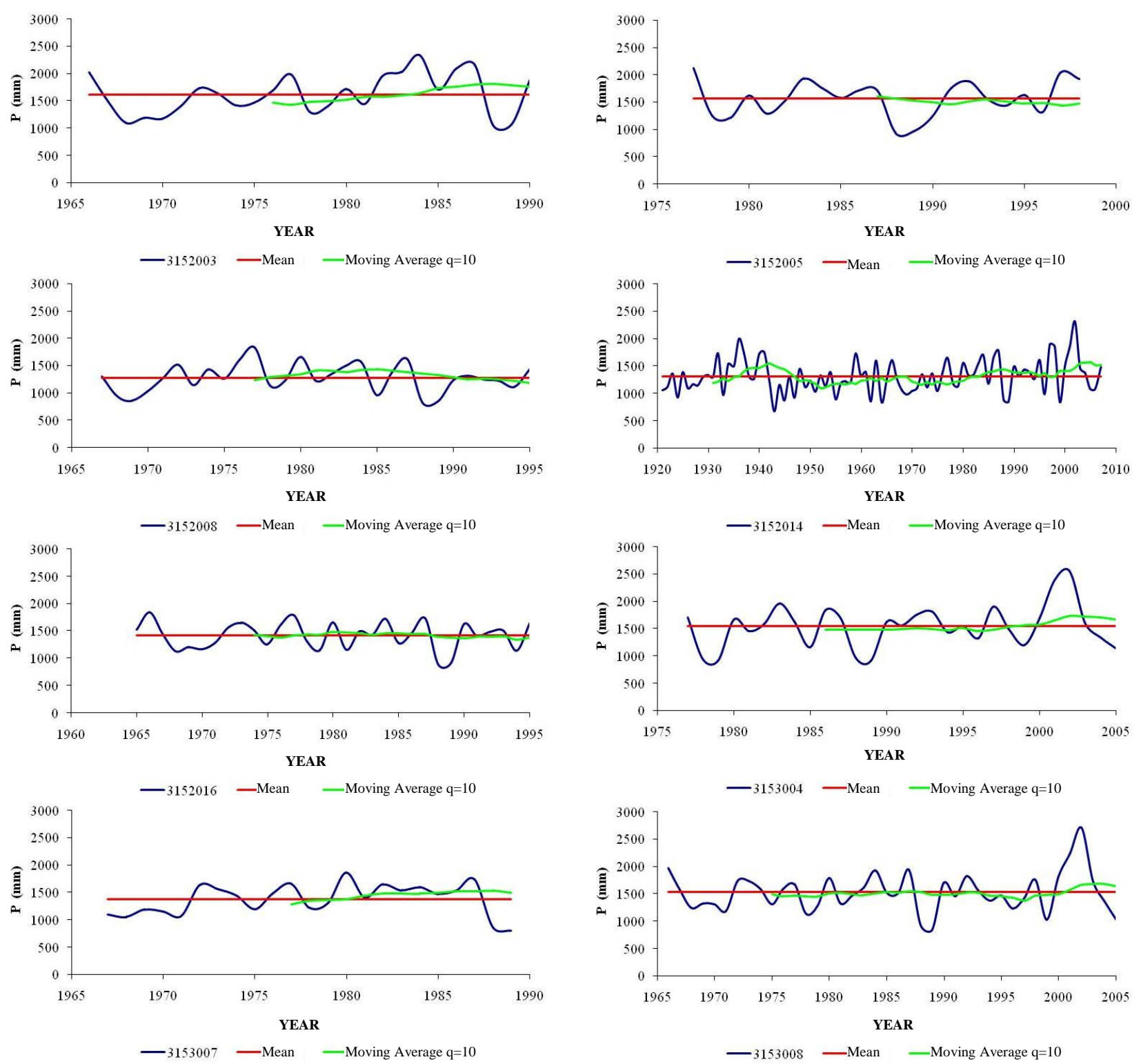

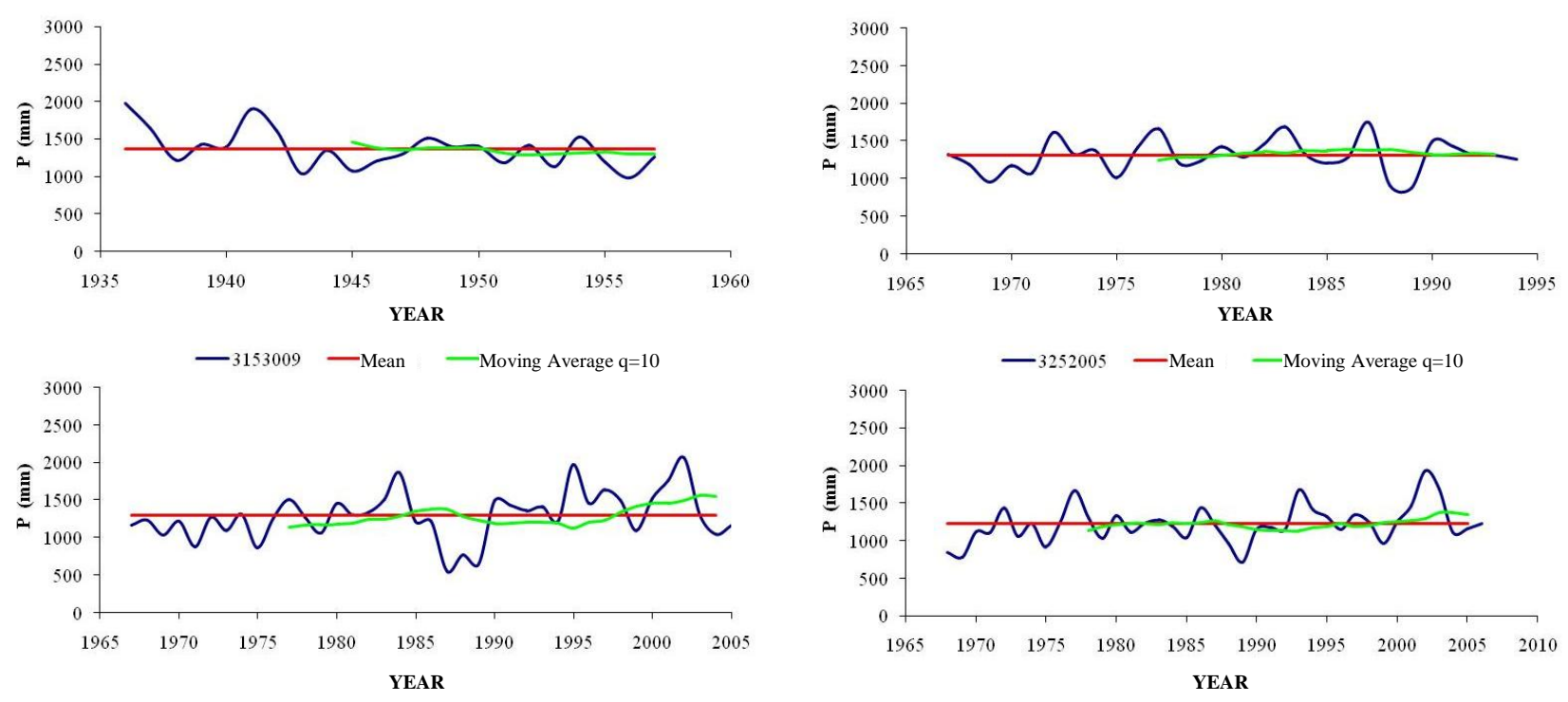

—3253001 —Mean —Moving Average $\mathrm{q}=10$
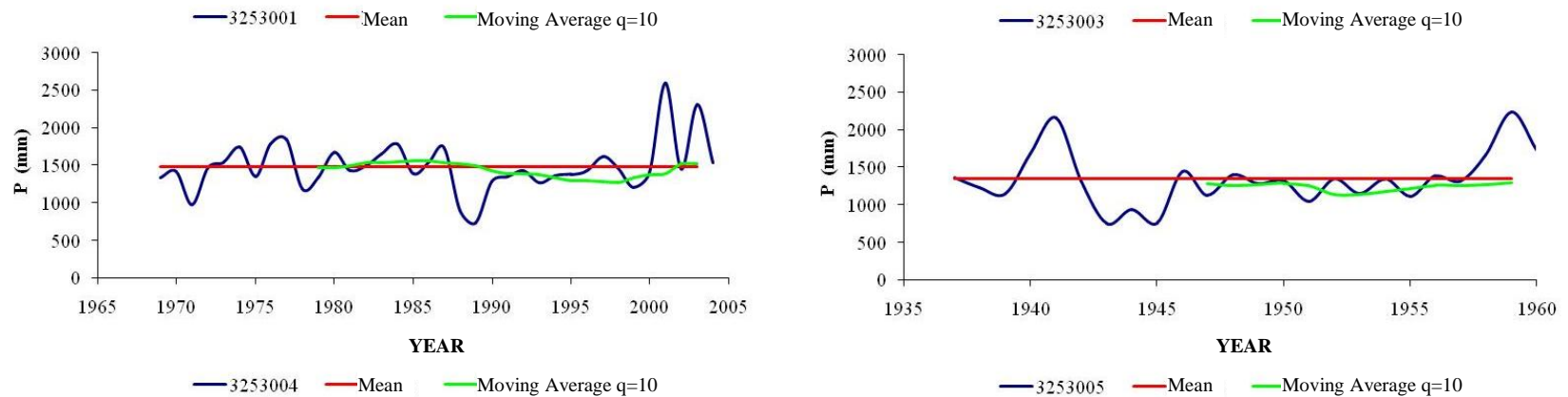

FIGURE 1. Series of precipitation, mean and moving average, of the 14 weather stations analyzed.

Table 4 presents the periods in which all series of precipitation and their respective statistics were subdivided. It was observed that for most of the stations, except the station 3152014 (Pelotas), the division of the series in two periods was considered. It is worth noting that this season has 87 values, whose first registration dates of January 1921, showing therefore more probability of trend change due to the size of the series.

According XU et al. (2003), the criterion for subdivision must be based on the existence of marked difference between the precipitation values of the series and its mean value, as well as the requirement of its length, i.e., at any selected partition, the length of the resulting records after subdivision must allow the application of appropriate statistical tests. 
TABLE 4. Descriptive statistics of precipitation values from the 14 weather stations analyzed after subdividing the series.

\begin{tabular}{|c|c|c|c|c|c|}
\hline Station & Series & $\mathrm{n}$ & $\begin{array}{l}\text { Mean } \\
(\mathrm{mm})\end{array}$ & $\begin{array}{l}\text { Stand. Dev. } \\
(\mathrm{mm})\end{array}$ & C.V. \\
\hline \multirow[t]{2}{*}{3152003} & $1966-1983$ & 18 & 1563.2 & 299.0 & 0.19 \\
\hline & $1984-1990$ & 7 & 1757.2 & 517.6 & 0.29 \\
\hline \multirow[t]{2}{*}{3152005} & $1977-1988$ & 12 & 1556.3 & 333.6 & 0.21 \\
\hline & $1989-1998$ & 10 & 1572.8 & 337.2 & 0.21 \\
\hline \multirow{2}{*}{3152008} & $1967-1983$ & 17 & 1310.3 & 257.9 & 0.19 \\
\hline & $1984-1995$ & 12 & 1232.9 & 258.9 & 0.21 \\
\hline \multirow[t]{3}{*}{3152014} & $1921-1952$ & 32 & 1279.8 & 295.3 & 0.23 \\
\hline & $1953-1973$ & 21 & 1214.6 & 242.2 & 0.20 \\
\hline & $1974-2007$ & 34 & 1405.9 & 327.1 & 0.23 \\
\hline \multirow{2}{*}{3152016} & $1965-1984$ & 21 & 1214.6 & 242.2 & 0.20 \\
\hline & $1985-1995$ & 10 & 1380.2 & 298.2 & 0.22 \\
\hline \multirow[t]{2}{*}{3153004} & $1977-1996$ & 20 & 1472.5 & 329.9 & 0.22 \\
\hline & $1997-2005$ & 9 & 1699.9 & 497.5 & 0.29 \\
\hline \multirow[t]{2}{*}{3153007} & $1967-1980$ & 14 & 1349.7 & 255.9 & 0.19 \\
\hline & $1981-1989$ & 9 & 1400.0 & 335.8 & 0.24 \\
\hline \multirow[t]{2}{*}{3153008} & $1966-1991$ & 26 & 1486.7 & 292.7 & 0.20 \\
\hline & $1992-2005$ & 14 & 1611.8 & 456.7 & 0.28 \\
\hline \multirow[t]{2}{*}{3153009} & $1936-1950$ & 15 & 1431.5 & 268.2 & 0.19 \\
\hline & $1951-1957$ & 7 & 1241.9 & 180.6 & 0.15 \\
\hline \multirow{2}{*}{3252005} & $1967-1983$ & 17 & 1320.9 & 213.2 & 0.16 \\
\hline & $1984-1994$ & 11 & 1286.7 & 244.1 & 0.19 \\
\hline \multirow[t]{2}{*}{3253001} & $1967-1987$ & 22 & 1201.7 & 279.5 & 0.23 \\
\hline & $1988-2005$ & 17 & 1374.2 & 367.0 & 0.27 \\
\hline \multirow[t]{2}{*}{3253003} & $1968-1996$ & 30 & 1170.9 & 208.9 & 0.18 \\
\hline & $1997-2006$ & 9 & 1340.2 & 305.5 & 0.23 \\
\hline \multirow[t]{2}{*}{3253004} & $1969-1991$ & 24 & 1444.1 & 300.2 & 0.21 \\
\hline & $1992-2004$ & 12 & 1585.5 & 422.4 & 0.27 \\
\hline \multirow[t]{2}{*}{3253005} & $1937-1951$ & 16 & 1269.7 & 342.2 & 0.27 \\
\hline & $1952-1960$ & 8 & 1494.0 & 373.9 & 0.25 \\
\hline
\end{tabular}

Table 5 presents the results of statistics of " $t$ " tests (parametric) and Mann-Whitney test (nonparametric). The test results relate to the use of the statistic in each " $n$ " period in which the series was subdivided. It is observed that, of the 14 stations analyzed, only in the station 3152014 (Pelotas), the null hypothesis was rejected at a significance level of 5\% when it was used the precipitation data of the periods from 1953 to 1973 and from 1974 to 2007, meaning that there was a change in the trend of annual precipitation in the locality of Pelotas. BLAIN et al. (2009), applying the likelihood ratio test, also found a trend of increasing change in precipitation regime in Pelotas-RS, for the periods from 1948 to 1976 and from 1977 to 2005.

In order to better visualize the behavior of annual precipitation of station 3152014 (Pelotas), the values of progressive mean and sample mean are shown in Figure 2. It is observed that between the years 1940 to 1979 - 40 years, the values found are below $(1212.86 \mathrm{~mm})$ the mean value $(1397.50 \mathrm{~mm})$, which means that, in the period between 1921 and $1940(1347.02 \mathrm{~mm})$, there was a trend of decreasing the annual precipitation value, while in the period from 1980 to 2007 the trend was to increase the blade, since the mean value of the period was $1430.91 \mathrm{~mm}$. 
TABLE 5. Results of " $t$ " test of Student and Mann-Whitney test of annual precipitation series.

\begin{tabular}{cccccccc}
\hline Station & $\mathrm{n}$ & $\mathrm{t}_{\text {calc }}$ & $\mathrm{t}_{\text {tab }}$ & $\mathrm{H}_{0}(\mathrm{t})$ & $\mathrm{Z}_{\text {calc }}$ & $\mathrm{Z}_{\text {tab }}$ & $\mathrm{H}_{0}(\mathrm{Z})$ \\
\hline 3152003 & $18-7$ & 1.18 & 2.07 & $\mathrm{~A}$ & 1.02 & 1.96 & $\mathrm{~A}$ \\
3152005 & $12-10$ & 0.11 & 2.09 & $\mathrm{~A}$ & 0.20 & 1.96 & $\mathrm{~A}$ \\
3152008 & $17-12$ & 0.80 & 2.05 & $\mathrm{~A}$ & 0.62 & 1.96 & $\mathrm{~A}$ \\
3152014 & $32-21$ & 0.87 & 2.01 & $\mathrm{~A}$ & 0.90 & 1.96 & $\mathrm{~A}$ \\
& $21-34$ & 2.32 & 2.01 & $\mathrm{R}$ & 2.23 & 1.96 & $\mathrm{R}$ \\
3152016 & $21-10$ & 0.59 & 2.05 & $\mathrm{~A}$ & 0.42 & 1.96 & $\mathrm{~A}$ \\
3153004 & $20-9$ & 1.46 & 2.05 & $\mathrm{~A}$ & 0.84 & 1.96 & $\mathrm{~A}$ \\
3153007 & $14-9$ & 0.41 & 2.08 & $\mathrm{~A}$ & 0.63 & 1.96 & $\mathrm{~A}$ \\
3153008 & $26-14$ & 1.06 & 2.05 & $\mathrm{~A}$ & 0.68 & 1.96 & $\mathrm{~A}$ \\
3153009 & $15-7$ & 1.69 & 2.09 & $\mathrm{~A}$ & 1.59 & 1.96 & $\mathrm{~A}$ \\
3252005 & $17-11$ & 0.39 & 2.06 & $\mathrm{~A}$ & 0.26 & 1.96 & $\mathrm{~A}$ \\
3253001 & $22-17$ & 1.67 & 2.03 & $\mathrm{~A}$ & 1.45 & 1.96 & $\mathrm{~A}$ \\
3253003 & $30-9$ & 1.62 & 2.03 & $\mathrm{~A}$ & 1.20 & 1.96 & $\mathrm{~A}$ \\
3253004 & $24-12$ & 1.30 & 2.03 & $\mathrm{~A}$ & 0.33 & 1.96 & $\mathrm{~A}$ \\
3253005 & $16-8$ & 1.47 & 2.07 & $\mathrm{~A}$ & 1.28 & 1.96 & $\mathrm{~A}$ \\
\hline
\end{tabular}

A: accept the null hypothesis $\left(\mathrm{H}_{0}\right)$ at $5 \%$ probability, $\mathrm{R}$ : reject the null hypothesis $\left(\mathrm{H}_{0}\right)$ at $5 \%$ probability.

Analyzing the methodologies of the series subdivision regarding the moving average (Figure 1) and the progressive mean (Figure 2), it is observed that the data of total precipitation present a marked difference in the mean value of itself. Although there is no perfect coincidence in the indication periods of subdivision, it was statistically confirmed from the results of " $\mathrm{t}$ " test (parametric) and Mann-Whitney tests (nonparametric) (Table 4), regardless the methodology used, rejection of the null hypothesis, showing the trend change in the population from which the data sample was drawn.

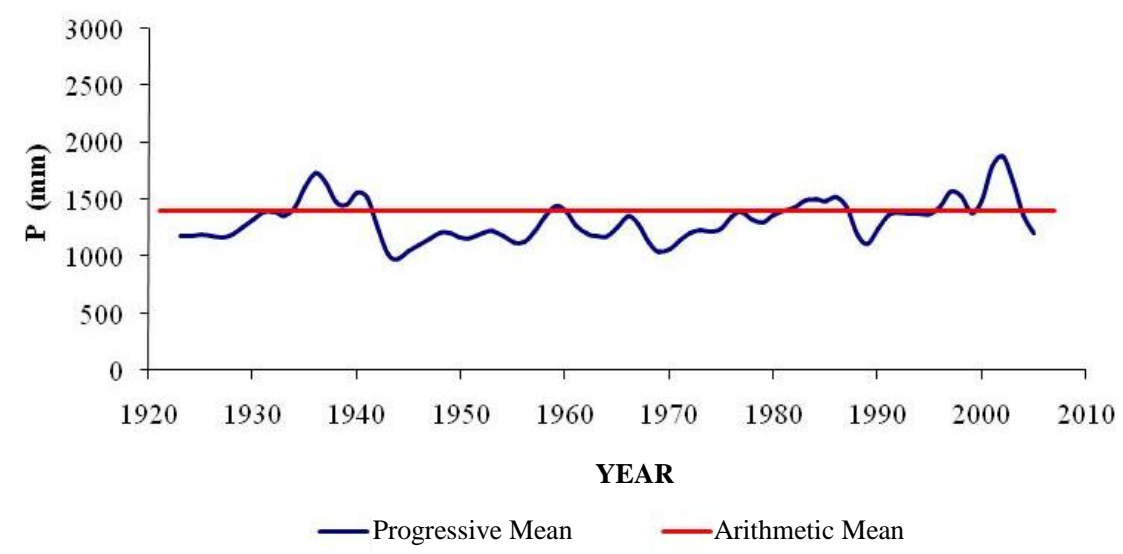

FIGURE 2. Arithmetic and progressive mean of total annual precipitation of 3152014 station (Pelotas) in the period from 1921 to 2007.

Although the results obtained from the "t" and Mann-Whitney tests have detected trend change, when it was applied the Mann-Kendall test (Table 6), which considers the total period of the series (1921 to 2007) of 3152014 station (Pelotas) there was no evidence of change tendency, since $\mathrm{Z}_{\text {calc }}$ was below the critical value of the statistic (1.96) for the probability level of $5 \%$. When applying the Mann-Kendall test, the series with $\mathrm{N}=87$ values was used, while for the " $\mathrm{t}$ " and Mann-Whitney tests, $\mathrm{n}_{1}=21$ and $\mathrm{n}_{2}=34$ are less than $\mathrm{N}$ (Table 4), which may have contributed to the differences found.

In other seasons, the samples may be considered homogeneous, i.e., there is no evidence of a trend change in precipitation series, when applying statistical tests (Tables 5 and 6). 
TABLE 6. Mann-Kendall statistic values for the 14 weather stations analyzed.

\begin{tabular}{ccc}
\hline Station & $\mathrm{Z}_{\text {calc }}$ & $\mathrm{H}_{0}(\mathrm{Z})$ \\
\hline 3152003 & 0.12 & $\mathrm{~A}$ \\
3152005 & 0.00 & $\mathrm{~A}$ \\
3152008 & 0.09 & $\mathrm{~A}$ \\
3152014 & 0.00 & $\mathrm{~A}$ \\
3152016 & 0.08 & $\mathrm{~A}$ \\
3153004 & 0.09 & $\mathrm{~A}$ \\
3153007 & 0.03 & $\mathrm{~A}$ \\
3153008 & 0.01 & $\mathrm{~A}$ \\
3153009 & 0.00 & $\mathrm{~A}$ \\
3252005 & 0.04 & $\mathrm{~A}$ \\
3253001 & 0.00 & $\mathrm{~A}$ \\
3253003 & 0.01 & $\mathrm{~A}$ \\
3253004 & 0.14 & $\mathrm{~A}$ \\
3253005 & 0.00 & $\mathrm{~A}$ \\
\hline
\end{tabular}

According to the results found, questions emerge about the natural and anthropogenic motivations that led to the trend change of the values of the total annual precipitation. Researchers like HOOPER et al. (2005) and SANTOS \& BRITO (2007) claim that anthropogenic factors, such as deforestation and misuse of ecosystems, may modify the climate of a region, contributing to the changes in the global system.

\section{CONCLUSIONS}

The number of elements in the series of annual precipitation influences on the test results of the trend analysis, whether they are parametric (Student " $t$ " test) or nonparametric (Mann-Whitney test).

It is possible to use the Student " $t$ " test (parametric) to detect trend change in the series of mean annual precipitation.

The tests for trend detection, which come in its methodological framework the subdivision of the series, were adequate, while the Mann-Kendall test (nonparametric), which uses the complete series, was not able to record the trend when it occurred.

\section{REFERENCES}

ALEXANDRE, G.R.; BAPTISTA, M.B.; NAGHETTINI, M. Estudo para identificação de tendências do regime pluvial na região metropolitana de Belo Horizonte a partir de métodos estatísticos. Revista Brasileira de Recursos Hídricos, Porto Alegre, v.15, n.2, p.115-126, 2010.

ANA. Agência Nacional de Águas. HidroWeb: sistemas de informações hidrológicas. Disponível em: <http://hidroweb.ana.gov.br/HidroWeb>. Acesso em: 5 ago. 2011.

BLAIN, G.C. Tendências e variações climáticas em séries anuais de precipitação pluvial do estado de São Paulo. Bragantia, Campinas, v.69, n.3, p.765-770, 2010.

BLAIN, G.C.; KAYANO, M.T.; CAMARGO, M.B.P.; LULU, J. Variabilidade amostral das séries mensais de precipitação pluvial em duas regiões do Brasil: Pelotas-RS e Campinas-SP. Revista Brasileira de Meteorologia, Piracicaba, v.24, n.1, p.1-11, 2009.

CHEN, Y.N.; LI, W.H.; XU, C.C.; HAO, X.M. Effects of climate change on water resources in Tarim River Basin, Northwest China. Journal of Environmental Sciences, Beijing, v.19, n.4, p.488493, 2007. 
FRANCO, C.M.; GODOI, H. Chuvas e umidade relativa do ar em Campinas de 1890 a 1945. Bragantia, Campinas, v.6, n.5, p.217-237, 1946.

HOOPER, D.U.; CHAPIN, F.S.; EWEL, J.J.; HECTOR, E.; INCHAUSTI, P.; LAVOREL, S.; LAWTON, J.H.; LODGE, D.M.; LOREAU, M.; NAEEM, S.; SCHMID, B.; SETALA, H.; SYMSTAD, A.J.; VANDERMEER, J.; WARDLE, D.A. Effects of biodiversity on ecosystem functioning: A consensus of current knowledge. Ecological Monographs, New York, v.75, p.3-35, 2005.

IPCC. Intergovernmental Panel on Climate Change. Climate Change 2007 - the physical science basis. Cambridge: Cambridge University Press, 2007.

KUNDZEWICZ, Z.W.; ROBSON, A.J. Change Detection in Hydrological Records - A Review of the Methodology. Hydrological Sciences Journal, Oxford, v.49, n.1, p.7-19, 2004.

LANG, M.; RENARD, B. Analyse régionale sur les extrêmes hydrométriques en France: détection de changements cohérents et recherche de causalité hydrologique. La HouilleBlanche, Paris, n.6, p.83-89, 2007.

MARENGO, J.A. Mudanças climáticas globais e seus efeitos sobre a biodiversidade caracterização do clima atual e definição das alterações climáticas para o território brasileiro ao longo do século XXI. 2. ed. Brasília: Ministério do Meio Ambiente, 2007. v.1, p.214.

MELLO, C.R.; SILVA, A.M. Modelagem estatística da precipitação mensal e anual e no período seco para o estado de Minas Gerais. Revista Brasileira de Engenharia Agrícola e Ambiental, Campina Grande, v.13, n.1, p.68-74, 2009.

QUADROS, L.E.; QUEIROZ, M.M.F.; VILAS BOAS, M.A. Distribuição de frequência e temporal de chuvas intensas. Acta Scientiarum Agronomy, Maringá, v.33, n.3, p.401-410, 2011.

SANTOS, C.A.C.; BRITO, J.I.B. Análise dos índices de extremos para o semi-árido do Brasil e suas relações com TSM e IVDN. Revista Brasileira de Agrometeorologia, Piracicaba, v.22, n.3, p.303-312, 2007.

SILVA, G.B.; AZEVEDO, P.V. Índices de tendências de mudanças climáticas no estado da Bahia. Engenharia Ambiental, Espírito Santo do Pinhal, v.5, n.3, p.141-151, 2008.

SILVA, V.P.R.; PEREIRA, E.R.R.; AZEVEDO, P.V.; SOUSA, F.A.S.; SOUSA, I.F. Análise da pluviometria e dias chuvosos na região Nordeste do Brasil. Revista Brasileira de Engenharia Agrícola e Ambiental, Campina Grande, v.15, n.2, p.131-138, 2011.

TEIXEIRA, C.F.A.; DAMÉ, R.C.F.; ROSSKOFF, J.L.C. Intensity-duration-frequency ratios obtained from annual records and partial records in the locality Pelotas-RS, Brazil. Engenharia Agrícola, Jaboticabal, v.31, n.4, p.687-694, 2011.

TRENBERTH, K.E.; JONES, P.D.; AMBENJE, P.; BOJARIU, R.; EASTERLING, D.; KLEIN TANK, A.; PARKER, D.; RAHIMZADEH, F.; RENWICK, J.A.; RUSTICUCCI, M.; SODEN, B.; ZHAI, P. Observations: Surface and Atmospheric Climate Change. In: SOLOMON, S. D. et al. (Ed.). Climate change 2007: The physical science basis. Cambridge: Cambridge University Press, 2007.

TUCCI, C.E.M. Modelos hidrológicos. Porto Alegre: UFRGS, 2005. 678 p.

XU, Z.X.; TAKEUCHIA, K.; ISHIDAIRAA, H. Monotonic trend and step changes in Japanese precipitation. Journal of Hydrology, Amsterdam, v.279, p.144-150, 2003. 